\title{
Efektifitas Undang - Undang No. 22 Tahun 2009 Tentang Lalu Lintas dan Angkutan Jalan Dalam Menyalakan Lampu di Siang Hari (Studi di Selong Kabupaten Lombok Timur)
}

\author{
Baiq. Ishariaty Wika Utary \\ Akademi Sekretari dan Manajemen Mataram \\ Luisadi645@gmail.com
}

\begin{abstract}
Abstrak-Peraturan untuk menyalakan lampu utama sepeda motor di siang hari ditetapkan untuk menjaga keselamatan para pengguna jalan raya. Sebenarnya aturan menyalakan lampu di siang hari atau light on ini sudah dikenalkan lebih dari satu tahun, untuk menyalakan lampu pada siang hari, namun hingga saat ini tingkat kesadaran masyarakat terhadap program light on atau menyalakan lampu pada siang hari yang bertujuan untuk mengurangi angka kecelakaan lalu lintas, sepertinya masih lemah. Hal tersebut terlihat di beberapa titik ruas jalan serta perempatan lalu lintas di daerah Selong Kabupaten Lombok Timur, banyak pengendara yang belum mematuhi kewajiban menyalakan lampu pada siang hari. Berdasarkan uraian dalam latar belakang di atas maka penyusun merumuskan permasalahan sebagai berikut :1.Bagaimana pengaturan Undang - Undang No. 22 Tahun 2009 tentang Lalu Lintas dan Angkutan Jalan dalam menyalakan lampu di siang hari?2.Bagaimanakah efektifitas penerapan light on di Selong Kabupaten Lombok Timur ?.Jenis penelitian yang digunakan adalah penelitian hukum empiris. metode pendekatan yang digunakan adalah : Pendekatan perundang - undangan, Pendekatan Konseptual, Pendekatan sosiologis. Undang-Undang Nomor 22 Tahun 2009 tentang Lalu lintas dan Angkutan Jalan 1. Terdiri dari 22 BAB dan 326 Pasal.Baru dijabarkan dengan 4 Peraturan Pemerintah (PP) dari yang seharusnya 25 PP antara lain:1) PP Nomor 32 Tahun 2011, tentang Manajemen dan Rekayasa, Analisis Dampak serta Manajemen Kebutuhan lalu lintas.2) PP Nomor 37 Tahun 2011, tentang Forum Lalu Lintas dan Angutan Jalan.3) PP Nomor 80 Tahun 2012, tentang Tata Cara Pemeriksaan Kendaraan Bermotor di Jalan.4) PP Nomor 55. Tahun 2012, tentang Kendaraan. Kepolisian Resort Lombok Timur khususnya Satuan Lalu Lintas telah melakukan berbagai upaya untuk memperkenalkan UndangUndang Lalu Lintas Nomor 22 tahun 2009 tentang Lalu Lintas dan Angkutan Jalan khususnya dalam penerapan light on. Kesimpulan, Dasar hukum light on atau DRL (Daytime Running Lights) adalah Pasal 107 dan sanksinya pada Pasal 293 Undang-undang Nomor 22 Tahun 2009 Tentang Lalu Lintas dan Angkutan Jalan, yang disahkan pada tanggal 22 juni 2009. Undang-undang ini tidak berjalan semestinya di Selong Kabupaten Lombok Timur, karena penerapan sanksi yang seharusnya tercantum pada Pasal 293 Undang-undang Nomor 22 Tahun 2009 belum diberlakukan secara merata dan efektif, Untuk penerapan Light on di Selong Kabupaten Lombok Timur SATLANTAS Polres Lombok Timur telah melakukan berbagai macam cara untuk mensosialisasikan Undang-undang Nomor 22 Tahun 2009 Tentang Lalu lintas dan Angkutan Jalan, khususnya dalam mensosialisasikan light on. Namun sampai saat ini respon masyarakat sangat kurang terhadap program POLRI. Oleh karena itu, sampai saat ini program light on masih berupa himbauan dan belum ada sanksi tegas terhadap pengendara yang belum melaksanakannya. Belum ada kesadaran dari masyarakat untuk mematuhi program light on ini.
\end{abstract}

Kata Kunci: efektifitas, lalu lintas, angkutan jalan

\section{Latar Belakang}

Dalam Undang-Undang Nomor 22 Tahun 2009 Tentang lalu lintas dan angkutan jalan, dijelaskan bahwa "untuk keselamatan, keamanan, ketertiban dan kelancaran lalu lintas serta memudahkan bagi pemakai jalan, maka jalan wajib dilengkapi dengan rambu- rambu lalu lintas." Di samping itu dalam tata laksana lalu lintas upaya-upaya dalam menuntun, mengarahkan, memperingatkan, melarang dan sebagainya atau lalu lintas yang ada dengan sedemikian rupa agar lalu lintas dapat bergerak dengan aman, lancar, dan nyaman disepanjang jalur lalu lintas pengguna jalan harus mematuhi peraturan lalu lintas.

Dalam Undang - Undang Lalu Lintas Angkutan Jalan Nomor 22 tahun 2009 pada Pasal 107, terdapat aturan yang 
memberlakukan penggunaan lampu utama pada kendaraan roda dua di siang hari atau light on. Namun aturan yang sempat berlaku beberapa waktu lalu itu masih belum populer di Indonesia. Kita lihat di ruas jalan terlihat banyak pengendara motor masih belum menyalakan lampu. Berdasarkan Undang- undang Nomor 22 Tahun 2009 tentang Lalu Lintas, pengemudi kendaraan roda dua wajib untuk menyalakan lampu utama pada siang hari. Bagi mereka yang tidak mengindahkan peraturan ini, bisa dikenakan tilang. Peraturan untuk menyalakan lampu utama sepeda motor di siang hari ditetapkan untuk menjaga keselamatan para pengguna jalan raya. Sebenarnya aturan menyalakan lampu di siang hari atau light on ini sudah dikenalkan lebih dari satu tahun, untuk menyalakan lampu pada siang hari, namun hingga saat ini tingkat kesadaran masyarakat terhadap program light on atau menyalakan lampu pada siang hari yang bertujuan untuk mengurangi angka kecelakaan lalu lintas, sepertinya masih lemah. Hal tersebut terlihat di beberapa titik ruas jalan serta perempatan lalu lintas di daerah Selong Kabupaten Lombok Timur, banyak pengendara yang belum mematuhi kewajiban menyalakan lampu pada siang hari. Meskipun sudah banyak sosialisasi yang dilakukan oleh petugas satlantas, namun banyaknya pengendara roda dua yang belum atau tidak menyalakan lampu utama sepeda motor mereka pada siang hari tersebut, menunjukkan kurangnya respon masyarakat terhadap program POLRI, dan polisi lalu lintas dituntut untuk mensosialisasikan program light on ini. Jika dahulu aturan menyalakan lampu masih dalam himbauan. Tetapi sejak 22 Juni 2009 lalu, Undang- Undang tersebut telah disahkan dan diatur dalam ketentuan undang-undang 22 tahun 2009, tentang Lalu Lintas dan Angkutan Jalan.

Berdasarkan uraian dalam latar belakang di atas maka penyusun merumuskan permasalahan sebagai berikut

1. Bagaimana pengaturan Undang Undang No. 22 Tahun 2009 tentang Lalu Lintas dan Angkutan Jalan dalam menyalakan lampu di siang hari?
2. Bagaimanakah efektifitas penerapan light on di Selong Kabupaten Lombok Timur?

\section{Tinjauan Pustaka}

\section{a. Konsep Tentang Pelanggaran Lalu Lintas}

pelanggaran lalu lintas adalah merupakan pelanggaran terhadap keamanan dan ketertiban umum, maka pribadi yang memperoleh sanksi hukum yang terlalu ringan akan merasa bahwa pelanggaran lalu lintas yang dilakukan dianggap terlalu ringan sifatnya sehingga rasa bersalah (sence of quilty) sangat tipis, terutama pribadi- pribadi yang digolongkan sebagai pengemudi ugalugalan di jalan raya.

\section{b. Konsep Pengaturan Menyalakan Lampu Di Siang Hari (Light On)}

Pasal 107 Undang-Undang No. 22 Tahun 2009 tentang Lalu Lintas dan Angkutan Jalan (“UU LLAJ") berikut:

(1) Pengemudi Kendaraan Bermotor wajib menyalakan lampu utama Kendaraan Bermotor yang digunakan di Jalan pada malam hari dan pada kondisi tertentu.

(2) Pengemudi Sepeda Motor selain mematuhi ketentuan sebagaimana dimaksud pada ayat (1) wajib menyalakan lampu utama pada siang hari.

Menurut penjelasan Pasal 107 ayat (1) UU LLAJ, yang dimaksud dengan "kondisi tertentu" adalah kondisi jarak pandang terbatas karena gelap, hujan lebat, terowongan, dan kabut.

c. Tinjauan Umum Pelanggaran Lalu Lintas

Pada dasarnya pelanggaran lalu lintas dapat dibedakan menjadi dua macam, yaitu :

1. Pelanggaran lalu lintas bersifat umum

Pelanggaran ini dibedakan menjadi tiga macam, yaitu:

a. Pelanggaran terhadap rambu lalu lintas 
Tujuan pemasangan rambu lalu lintas adalah agar lalu lintas dapat lancar, sehingga pemakai jalan merasa aman dan nyaman mengendarai kendaraanya. Namun demikian pemakai jalan yang tidak mengindahkan ramburambu lalu lintas. Pelanggaran yang sering menjadi penyebab kemacetan lalu lintas adalah:

1). Pelanggaran terhadap rambu pengaturan lalu lintas

\section{2). Pelanggaran terhadap penyebrang}

Selain dapat menimbulkan kemacetan lalu lintas, bahkan juga bisa menimbulkan kecelakaan.

b. Pelanggaran terhadap kelengkapan kendaraan

Disamping
pelanggaran-pelanggaran tanya
rambu-rambu lalu lintas yang
menyebabkan kemacetan maupun
kecelakaan lalu lintas yang
mengakibatkan korban jiwa dan harta,
masih adanya pelanggaran yang
menyangkut kelangkapan kendaraan
yaitu:

1) Syarat - syarat kendaraan:

a) Surat tanda Nomor Kendaraan (STNK)

b) Surat Tanda Coba Kendaraan (STCK), dan Surat tanda Uji Kelayakan (STUK) bagi kendaraan umum.

2) Pelanggaran kendaraan

Kelengkapan ini adalah kelengkapan yang ada pada kendaraan itu sendiri yang sudah ada sejak dari pabriknya, misalnya: kaca spion, lampu penerangan, lampu petunjuk arah dan lainlain. Kelengkapan kendaraan ini dimaksud untuk keamanan pengemudi itu sendiri dan keamanan pemakai jalan lainnya, sehingga akan tercipta suatu arus lalu lintas yang tertib, lancar dan aman. Pelanggaran pengemudi dalam pemakaian jalan.

\section{Pelanggaran yang bersifat khusus}

Pelanggaran ini diartikan sebagai setiap pelanggaran lalu lintas yang mengakibatkan mati maupun luka-luka. Apabila terjadi pelanggaran yang demikian ini maka si penguji terkena dua peraturan, yaitu:

a.Peraturan mengenai pelanggaran lalu lintas

b.Peraturan yang tersebut dalam KUHP yang mengakibatkan mati (pasal 359 KUHP) atau luka- luka (pasal 360 KUHP) bagi orang lain.

\section{Metode Penelitian}

Jenis penelitian yang digunakan adalah penelitian hukum empiris, yaitu penelitian hukum yang mengkaji peraturan perundang - undangan dan melihat kenyataan dilapangan. Dalam penulisan proposal penelitian skripsi ini, agar memenuhi kriteria ilmiah dan dapat mendekati kebenaran, maka metode pendekatan yang digunakan adalah :

a. Pendekatan perundang - undangan, yaitu pendekatan yang mengkaji tentang asas asas hukum, norma - norma hukum dan peraturan perundang - undangan.

b. Pendekatan Konseptual, yaitu pendekatan yang mengkaji buku - buku dan sumber - sumber resmi yang berkaitan dengan penulisan proposal penelitian skripsi ini.

c. Pendekatan sosiologis, yaitu berusaha untuk mengetahui keberlakuan atau penerapan aturan - aturan hukum dengan kenyataan yang ada ditengah - tengah masyarakat.

\section{Sumber Data}

a. Data Kepustakaan berupa data sekunder

1). Bahan hukum primer, yaitu bahan hukum yang memberikan penjelasan yang terdiri dari peraturan perundangundangan.

2). Bahan hukum sekunder, yaitu bahan hukum yang meliputi buku -buku, refrensi, makalah, hasil penelitian, dan lain-lain yang berkaitan dengan masalah yang diteliti. 
b. Data lapangan yaitu data yang diperoleh langsung dari informan yang langsung menangani masalah tersebut.

\section{Jenis Data}

a. Data sekunder, yaitu data yang diperoleh melalui studi kepustakaan

b. Data primer, yaitu data yang diperoleh secara langsung dari informan dengan wawancara langsung di Polres Lombok Timur. Yang menjadi informannya adalah petugas Satlantas Polres Lombok Timur dan pelaku yang menjadi penyebab kecelakaan lalu lintas.

\section{Teknik dan Alat Pengumpulan Data}

1. Wawancara atau interview, yaitu dengan mengadakan tanya jawab mengenai pokok-pokok permasalahan, baik pada responden maupun pejabat atau petugas yang menangani masalah tersebut,yang dilakukan dengan teknik wawancara langsung bersifat terbuka.

2. Studi dokumen, dimana dokumen ini merupakan data kepustakaan yang dikumpulkan dengan cara mengumpulkan dan membaca peraturan perundang undangan, literatur dan karya tulis.

\section{Hasil}

Profil Undang-Undang Nomor 22 Tahun 2009 tentang Lalu lintas dan Angkutan Jalan

1. Terdiri dari $22 \mathrm{BAB}$ dan 326 Pasal.

Baru dijabarkan dengan 4 Peraturan Pemerintah (PP) dari yang seharusnya 25 $P P$ antara lain:

1) PP Nomor 32 Tahun 2011, tentang Manajemen dan Rekayasa, Analisis Dampak serta Manajemen Kebutuhan lalu lintas.

2) PP Nomor 37 Tahun 2011, tentang Forum Lalu Lintas dan Angutan Jalan.

3) PP Nomor 80 Tahun 2012, tentang Tata Cara Pemeriksaan Kendaraan Bermotor di Jalan.

4) PP Nomor 55. Tahun 2012, tentang Kendaraan.

Dijabarkan dengan Peraturan Kapolri ( Perkap) antara lain:

1) Perkap Nomor 5 Tahun 2012 tentang Regident Ranmor (Registrasi dan Identifikasi Kendaraan Bermotor);
2) Perkap Nomor 9 Tahun 2012 tentang SIM;

3) Perkap Nomor 10 Tahun 2012 tentang Pengaturan Lalu Lintas Dalam Keadaan Tertentu Dan Penggunaan Jalan Selain Untuk Kegiatan Lalu Lintas

Dalam Undang - Undang tersebut disebutkan dalam Pasal 107 bahwasannya setiap kendaraan bermotor wajib menyalakan lampu utama di jalan pada siang hari, malam hari dan pada kondisi tertentu.

(1) Pengemudi kendaraan bermotor wajib menyalakan lampu utama kendaraan bermotor yang digunakan di jalan pada malam hari dan pada kondisi tertentu.

(2) Pengemudi sepeda motor selain mematuhi ketentuan sebagaimana dimaksud pada ayat (1) wajib menyalakan lampu utama pada siang hari.

Pasal ini yang menjadi dasar penerapan light on, sehingga light on menjadi salah satu point yang tercantum dalam Undang-undang Nomor 22 Tahun 2009 Tentang Lalu Lintas dan Angkutan Jalan. Karena light on ini telah diatur dalam Undang - Undang, maka apabila pengendara kendaraan bermotor tidak mematuhi peraturan yang tercantum pada Pasal 107 Undang-undang Nomor 22 Tahun 2009 Tentang Lalu Lintas dan Angkutan Jalan, akan dikenakan sanksi seperti yang terdapat pada Pasal 293 Undang-undang Nomor 22 Tahun 2009 Tentang Lalu Lintas dan Angkutan Jalan

Penerapan Light On di Selong Kabupaten Lombok Timur

Kepolisian Resort Lombok Timur khususnya Satuan Lalu Lintas telah melakukan berbagai upaya untuk memperkenalkan Undang-Undang Lalu Lintas Nomor 22 tahun 2009 tentang Lalu Lintas dan Angkutan Jalan khususnya dalam penerapan light on. Sosialisasi yang dilakukan dari pihak kepolisian bermacam cara dan bentuk yang disampaikan kepada masyarakat pengguna kendaraan bermotor untuk menerapkan peraturan light on sebagai langkah mengurangi angka kecelakaan di jalan raya. Bentuk upaya dari kepolisian dalam mensosialisasikan Undang-Undang Lalu Lintas Nomor 22 Tahun 2009, khususnya peraturan light on 
untuk masyarakat pengendara sepeda motor antara lain :

1. Himbauan kepada warga masyarakat melalui brosur, famlet, isyarat tangan, pemasangan papan, baliho, SATLANTAS menggunakan mobil patroli yang ditujukan kepada pemakai jalan dan seluruh masyarakat.

2. Penyuluhan kepada seluruh warga masyarakat melalui media elekronik dan cetak (melalui media cetak, radio, koran dan surat kabar, baliho-baliho yang dipasang di pinggir jalan), serta penyuluhan instansi baik sipil maupun swasta yang dilaksanakan oleh SATLANTAS dan masih banyak caracara yang dilaksanakan oleh kepolisian.

3. Menyampaikan langsung kepada pengendara sepeda motor, setiap melaksanakan pengaturan pagi hari menggunakan isyarat tangan.

4. Mengadakan penyuluhan ke sekolahsekolah yaitu Program Polisi Sahabat Anak.

5. Anggota SATLANTAS turun langsung ke jalan bertatapan dengan masyarakat, memberikan penyuluhan program light on.

\section{Kesimpulan}

1. Dasar hukum light on atau DRL (Daytime Running Lights) adalah Pasal 107 dan sanksinya pada Pasal 293 Undang-undang Nomor 22 Tahun 2009 Tentang Lalu Lintas dan Angkutan Jalan, yang disahkan pada tanggal 22 juni 2009. Undang-undang ini tidak berjalan semestinya di Selong Kabupaten Lombok Timur, karena penerapan sanksi yang seharusnya tercantum pada Pasal 293 Undangundang Nomor 22 Tahun 2009 belum diberlakukan secara merata dan efektif.

2. Untuk penerapan Light on di Selong Kabupaten Lombok Timur SATLANTAS Polres Lombok Timur telah melakukan berbagai macam cara untuk mensosialisasikan Undangundang Nomor 22 Tahun 2009 Tentang Lalu lintas dan Angkutan Jalan, khususnya dalam mensosialisasikan light on. Namun sampai saat ini respon masyarakat sangat kurang terhadap program
POLRI. Oleh karena itu, sampai saat ini program light on masih berupa himbauan dan belum ada sanksi tegas terhadap pengendara yang belum melaksanakannya. Belum ada kesadaran dari masyarakat untuk mematuhi program light on ini. Menurut masyarakat light on tidak berpengaruh dalam penurunan angka kecelakaan lalu lintas, sehingga dirasa lebih banyak merugikan, bila dibandingkan dengan manfaatnya.

3. Pengaruh utama terhadap tingkat kecelakaan adalah faktor manusia, faktor kendaraan, faktor jalan, dan faktor lingkungan. Dari data yang diperoleh dari SATLANTAS Polres Lombok Timur, light on tidak berpengaruh terhadap angka kecelakaan lalu lintas di Kabupaten Lombok Timur.

\section{DAFTAR PUSTAKA}

Amiruddin, M.Hum,SH, Pengantar Metode Penelitian Hukum, PT. Raja Grafindo, Mataram, 2003

Awaloedin, Prof, Peningkatan Disiplin Masyarakat Pemakai Jalan Raya Dalam Kaitannya dengan Wewenang Polri sebagai Penegak Hukum, Bina ilmu, Surabaya, 1983

Bambang, M.si, Drs, Menulis Artikel dan Karya IImiah, PT. Remaja rosda Karya, Surabaya, 2002

Kansil C.S.T, Drs, Pengantar IImu Hukum dan Tata Hukum Indonesia, Jakarta, 1989

Ramlan Naning, Msi. SH, Mengarahkan Kesadaran Hukum Masyarakat dan Disiplin Penegakan Hukum Dalam Lalu Lintas, PT. Bina ilmu, Surabaya, 1983

Rahardjo, Satjipto, Menuju Kepolisian Republik Indonesia Yang Profesional, Jakarta :Yayasan Tenaga Kerja, 2000

Soekanto, Soerjono, Inventarisasi dan Analisa terhadap Perundang Undangan Lalu lintas dan Angkutan Jalan, CV. Rajawali, jakarta, 1984

Soeroso, Pengantar Ilmu Hukum, Jakarta : Sinar Grafika, 2014

Subekti, Prof. SH, Kamus Hukum, Pradanya Pramita, Jakarta, 1985

Sugangga, SH, Inti Sari Pengantar Hukum Indonesia,Semarang, 1991 
Tiena Yulies, M.Hum, SH, Pengantar Hukum Indonesia, Jakarta, 2004 